\title{
The context and dynamics of the war in Congo-Kinshasa since August 1998
}

\author{
HEINRICH MATTHEE \\ Centre for Military Studies, University of Stellenbosch
}

\section{Introduction}

Thousands of fighters from at least eight African states and several insurgent groups are involved in a war in Congo-Kinshasa since 1998. This article investigates the context and dynamics of the war to determine the reasons for the conflict. The outcome of the conflict is still unpredictable at the time of writing and the article tentatively explores the chance for stability in Africa's third largest country.

The article begins with an analysis of the country's political order, the economic framework, regional dynamics, the impact of the rebellion of 1996-1997, Kabila's rule and the volatile security situation by 1998. The rebellions of 1996-1997 and 1998 are compared and the escalation of the 1998 rebellion into a regional war is traced. Finally, the article looks at the prospects for regional peace and stability in Congo-Kinshasa.

\section{The political order}

Congo-Kinshasa, to be distinguished from neighbouring Congo-Brazzaville, is also known as Zaïre under Mobutu Sese Seko and as the Democratic Republic of the Congo (DRC) under Kabila. The vast territory of 2,35 million square kilometers, limited technological ability and a large diverse population of 45 million people have limited the scope of post-colonial state control in Congo-Kinshasa.'

The political order consists, in the first place of inherited colonial state structures. Mobutu took over the state in a military coup d'etat in 1965 and ruled for 32 years. Mobutu, together with a small network of associates, mostly from Mobutu's Ngwandi group, controlled the capital of Kinshasa. ${ }^{2}$ However, while the presidential network had information about what was going on in the rest of the country, there was a limited ability to implement policies outside the capital.

Much of the weakness of the state structures to implement policies was related to neo-patrimonialism. Neo-patrimonialism means that, in spite of the colonial insertion of bureaucratic state structures, patrimonial features have persisted. Some patrimonial features of the rule of Mobutu included no clear distinction between public and private spheres and a strong personalisation of power relationships around Mobutu. ${ }^{3}$

Solomon, H., "From Zaïre to the Democratic Republic of the Congo: Towards post-Mobutuism" in Africa Insight 27 (2), 1997, pp. 91-97.

2 Weiss, H., "Zaïre: Collapsed Society, Surviving State, Future Polity", in Zartman, I. (ed.), Collapsed States - The Disintegration and Restoration of Legitimate Authority (Boulder, 1995), pp. 157-170. See also Chabal, P., Power in Africa: An Essay in Political Interpretation (London 1992), p. 216. 
Legitimation of the political system occurred through costly patronage of some clients while the eastern provinces were excluded from the same benefits of patronage.

The weakness of the neopatrimonial state revealed its narrow symbiosis with a limited number of social networks, dominated by people from the Ngwandi group. However, under Mobutu the state was especially weak because the presidential network exceeded the norms of reciprocity, inherent in patron-client ties, and made excessive use of state structures for private profit. ${ }^{4}$

Apart from central state structures, some local power structures from the precolonial and colonial era persisted in the post-colonial state. Regional and ethnic consciousness among the 250 language groups were not only political forces in themselves in the country, but even more a channel through which competition for wealth, power and status was expressed. ${ }^{5}$

Some local power structures in Katanga/Shaba, Kasai and the eastern Kivu provinces crystallized around resources, trade routes and clan networks and became virtually semi-autonomous over time. Competition and conflict over resources, including three percent arable land and rich reserves of diamonds, cobalt and copper, remained a strong driving force of politics in local and state structures in the country.

The concentration of control over many resources in state structures and the exclusion of different groups from the benefits of state patronage made it attractive to excluded groups to try and take over the state. Several regional rebellions, coup attempts and other forms of dissent therefore marked Mobutu's rule. However, a security force separate from the regular military, the Special Presidential Division (DSP), and especially French support allowed Mobutu to retain his grip on Kinshasa for decades.

In the nineties riots almost unseated Mobutu. Under pressure, Mobutu had to share power in new democratic structures. Mobutu re-established some of his authority over his opponents by different methods of division, deception and patronage. ${ }^{6}$ However, by 1996, as the state's income dropped, Mobutu had increasingly less money to buy off opposition and to ensure allegiance by client networks.

\section{The economic framework}

Already since the end of the eighties the country experienced a rapid decline in its formal economic sphere, with a significant drop in measurable mining and agriculture output and a reduced tax base. ${ }^{7}$ As a consequence, the government under Mobutu tried to

change (Evanston 1970), pp. 124-151. See also Callaghy, T., "The State as Lame Leviathan: The Patrimonial Administrative State in Africa", in Ergas, Z. (ed.), The African State in Transition (London 1987), pp. 87-115.

4 Chazan, N., Mortimer, R., Ravenhill, J. and Rothchild, D., Politics and Society in Contemporary Africa (Boulder 1992), p. 181. See also Chabal, p. 216 and New African, July/August 1997, pp. 12-14.

5 Bayart, J.-F., The State in Africa: The Politics of the Belly (London 1993), pp. 252-259.

6 Joseph, R., "Democratization in Africa after 1989: Comparative and Theoretical Perspectives" in Comparative Politics April 1997, pp. 363-375. See also Baker, B., "The Class of 1990: how have the autocratic leaders of sub-saharan Africa fared under democratisation" in Third World Quarterly 19 (1), 1998, pp. 115-127.

7 Africa Confidential, 25 April 1997, pp. 1-3. 
finance budgetary deficits by printing money, which led to hyperinflation exceeding 650 percent in 1996.

Apart from taxation, foreign aid also was an important source of state income. However, Western countries, the World Bank and the International Monetary Fund began to follow a gradualist approach to aid, premised on progress in economic and political reforms. The conditions of aid were not met in all cases and Mobutu sporadically put pressure on multinational and local firms in order to increase income and to promote political objectives. ${ }^{8}$

Informal markets provided a means to escape the predatory state, and both multinational and local firms dealt with the surging informal economic sphere. However, informal markets in the country did not only provide a means to escape a predatory state. When power appeared to recede in inefficient administrative structures, Mobutu, whose family was involved in the diamond trade, also sought opportunities and resources for supporters in informal markets. The state's resource base was weakened but the state endured because of the networks and alliances that were built. ${ }^{9}$

The presidential network used its links to the formal and informal economy for enrichment. The wealth was used for private purposes, to build patron-clients relations and to buy off some opposition. Wealth was often not used for development but rather used to establish symbolic authority over competing networks by conspicuous consumption. As a result, infrastructure outside Kinshasa was often allowed to decay, which meant that the eastern Kivu provinces became virtually cut off from central state services.

\section{Regional dynamics}

The weakness of state structures led to a loss of political control over the population and over economic space in the Kivu provinces. Currencies of neighbours like Rwanda and Uganda were used and a vast informal trade zone existed. ${ }^{10}$ Neighbouring rulers and their clients had interests in the formal and informal markets.

Congo-Kinshasa shares its land boundaries of 10000 kilometers with eight countries. These states are Rwanda, Uganda, Burundi, Sudan, Central African Republic, Congo-Brazzaville, Zambia and Angola. There are communities like the Tutsi who live on both sides of the borders drawn by the European colonial powers during the nineteenth century. The long shared borders and the fluidity of populations strengthen the effect of economic and political events in one country on other countries in the region.

Tutsi-Hutu animosities in the region had such a spillover effect. ${ }^{11}$ In 1994 the massacre of hundreds of thousands of Tutsi and Hutu moderates by Hutu soldiers and

Turner, T., "Zaïre: Flying High Above the Toads: Mobutu and Stalemated Democracy" in Clark, J. and Gardiner, D., Political Reform in Francophone Africa (Boulder 1997), pp. 246-264. See also Leslie, W., Zaïre: Contimuity and Political Change in an Oppressive State (Boulder 1993), p. 107.

Reno, W., Corruption and State Politics in Sierra Leone (Cambridge 1995), p. 19. See also Chabal, p. 227 and Bayart, pp. 237-241.

Turner, J., Continent Ablaze: The Insurgency Wars in Africa 1960 to the Present (Johannesburg 1998), pp. 221-223.

Clarke, W., "Waiting for "The Big One": Confronting Complex Humanitarian Emergencies and State Collapse in Central Africa" in Small Wars and Insurgencies 19, Spring 1998, pp. 702. See also Nzongola-Ntalaja, G. in "Conflict in Eastern Zaïre" in Africa Insight 26 (4), 1991, pp. 392-394. 
youth militia occurred in neighbouring Rwanda. Only an exile Tutsi military under Paul Kagame stopped the genocide, but fear of revenge by the Tutsi caused over a million Hutus to pour into the east of Congo-Kinshasa.

Thousands of Rwandan Hutu ex-soldiers and militiamen settled among the unarmed Hutus in border camps, and these armed groups used the cover of the refugee camps to launch attacks against Tutsi settlements in the region. Mobutu provoked the rulers of Rwanda by not doing anything to separate the refugees from the insurgents or to stop the attacks from his territory.

Similarly, the Ugandan government of Yoweri Museveni had to contend with insurgent groups supported by Sudan and operating from Congo-Kinshasa. ${ }^{12}$ The Rwandese vice-president Paul Kagame had been Museveni's chief of intelligence during the latter's insurgency campaign in Uganda, and the Museveni family also had Tutsi links.

Ethnic Tutsis have resided for generations in the east of Congo-Kinshasa and have family and business links in the region. The Mobutu government tried to deprive them of citizenship and tried to dislodge them from the land they occupied. Local groups like the Hunde and Nande used the opportunity to violently pursue land claims against these Tutsis, and when an estimated 2000 Congolese Tutsis were massacred in 1996, the Tutsis, Rwanda and Uganda became allies in an enterprise to remove Mobutu from power.

On 10 October 1996 the rebellion against Mobutu of the Alliance of Democratic Forces for the Liberation of Congo-Zaïre (AFDL) started. The AFDL embraced several groups from Congo-Kinshasa, including a group led by Andre Ngandu Kassasse and a group led by Laurent Kabila, a veteran guerilla opponent of Mobutu. During previous years Kabila had become relatively inactive, but he was known to Museveni and used as a Zaïrean spokesman for the rebellion. ${ }^{13}$ Nevertheless, the rulers of Uganda and especially of Rwanda provided the decisive support for the rebellion.

\section{The rebellion of 1996-1997}

The rebellion started in the east and the vanguard of the AFDL forces consisted of Rwandan and Congolese Tutsis. Mobutu's ill-disciplined and socially fragmented army was quickly routed in the east. As the AFDL forces advanced through the country, aided by the logistical ability of their sponsors Uganda and Rwanda, they recruited among the many teenagers who had marginal roles only in traditional communities and the system of patronage. $^{14}$

As the rebellion continued, Mobutu's forces started to suffer from a lack of manpower and funding, with much of the military budget siphoned off in corrupt procurement deals. Eventually France gave three million US dollars to pay for European mercenaries, who were unable to influence the course of the rebellion. ${ }^{15}$

Africa Confidential, 9 May 1997, pp. 1, 5-6. See also Solomon, p. 93.

Rosenblum, P., "Kabila's Congo" in Current History 97, May 1998, pp. 193-199.

For the importance of logistical capability during wars on the rough African terrain, see Du Plessis, L., "The historical development of sub-Saharan military capabilities" in Du Plessis, L. and Hough, M. (eds.), Protecting Sub-Saharan Africa: The Military Challenge (Pretoria 1999), pp. 43-46. 
Mobutu got some funds from business supporters, but the AFDL forces were also able to capture a number of mines and gold reserves. After the AFDL's military progress in late 1996, various multinational companies preferred to negotiate mining and commodity concessions with the AFDL in return for tax payments. These deals helped to fund the AFDL's increasingly successful rebellion. ${ }^{16}$

With funding and with the support of the rulers of Angola, Zimbabwe, Uganda and Rwanda, the AFDL started to advance on Kinshasa. Under pressure from the victorious AFDL forces, Mobutu's generals took control of arms purchases and told Mobutu he was an impediment to the ending of the war. Mobutu fled soon after and the AFDL installed Kabila as the new ruler of Congo-Kinshasa in May 1997.

\section{The significance of the rebellion of 1996-1997}

The successful rebellion of the AFDL in 1996-1997 influenced the context of the 1998 rebellion. While the rebellion did not change the political system of patronage, the Tutsi group became the group favoured by the state, substituting Mobutu's Ngwandi group. The quick and successful campaigns of the rebel forces demonstrated the lack of patronage-based government authority outside Kinshasa.

Previously France played a very important role in propping up the Mobutu government in Kinshasa. The outcome of the rebellion meant a setback to French influence in the region, but the Ugandan and Rwandan rulers also demonstrated their military ability to influence who will rule the third largest country in Africa. The rebellion did not change the historical feature that the government in Kinshasa needed foreign support and mercenaries to survive local challenges to its authority.

In addition, the rebellion meant that the new ruler had financial debts towards the rulers of Uganda, Rwanda, Angola and Zimbabwe, and that the Kabila government had to honour new contracts, made with mining companies in exchange for financial support during the rebellion. The cost of the war effort further depleted the limited funds of state structures and left Kabila with even fewer means to ensure client allegiance.

In addition to limited funds for patronage, Kabila could not rely on a strong personal network in Kinshasa itself. Most of his officials came from the east or from exile. Many soldiers of Mobutu's army also survived, forming a nucleus of potential resistance to the new ruler. The rebellion had the potential to establish a Tutsi zone of influence, which could accommodate the potentially disruptive Tutsi interests outside the established state. Eventually, however, the rebellion reinforced the statist framework.

\section{Kabila's rule}

In May 1997 Kabila changed the name of the state Zaïre to the Democratic Republic of the Congo. However, during the short period of his rule since he has not fundamentally changed the political order of Mobutu's 32 years of rule. Kabila's power still rests on military force, foreign support, patronage and a personal network.

After coming to power, Kabila promised a list of democratic reforms before certain dates in his inaugural address. However, no deadlines were met and security concerns remained predominant. Political activity was suspended and Kabila was awarded absolute power over policy and appointments for a two-year period before elections. 
Kabila invited Sakombi Inongo, the orchestrator of the Mobutu personality cult, as his communications adviser and Maoist education was introduced for the state administration. $^{17}$

Initially dependent on Rwandan and Congolese Tutsi backing, Kabila soon started to reduce the influence of the Tutsi and potential adversaries in his administration. People like the chief of staff of the army and several cabinet ministers were detained on charges ranging from drug trafficking to corruption, weakening the Kasai and Tutsi leadership element in the government. ${ }^{18}$

At the beginning of January 1998 Kabila carried out a major cabinet reshuffle where he gave his fellow Katangans decisive influence in the cabinet. Like Mobutu, Kabila started to build up a personal security unit, this time composed of his fellow Katangans. Like before, the presidential office and the military also remained the main beneficiaries of the state budget.

\section{The security situation under Kabila}

Kabila wanted to create a new military and faced the challenge of achieving cohesion between diverse groups, including exiles from Angola, Katangese youths, Congolese Tutsi and ex-Mobutu soldiers. The challenge was even greater because cohesion had to be improved while local conflicts still raged in the semi-autonomous Katanga and the eastern provinces.

In September 1997 the Congolese Tutsis were attacked once again by local militias in the east and thousands fled to Rwanda. Fighting also broke out between Kabila's Tutsi troops and their colleagues from Katanga. Like Mobutu before, the Kabila government had no military hierarchy with the ability to control the situation. ${ }^{19}$

Kabila's Rwandan-backed forces clashed repeatedly with fighters from the Bembe, Hunde and Nande groups, who initially formed part of the Tutsi-driven AFDL because they wanted more autonomy to protect their resources. This time the rebels relied on Rwandan Hutu forces for weaponry and logistics.

During the ongoing local conflicts, the army of Kabila fragmented into factions reflecting different social interests. ${ }^{20}$ Different pay scales between Tutsi, Katangese and ex-Mobutu soldiers, and favouritism towards soldiers from Kabila's home region, provoked rivalries and clashes. As in Mobutu's time, non-payment of salaries also became an issue. The economic weakness of state structures made it very difficult to improve the situation.

\section{Economic achievements and constraints}

Kabila inherited an economically weak state, vulnerable to the economic advances of neighbours in the border regions and scarcely able to implement plans for economic renewal. Nevertheless, with a well-managed central bank, hyperinflation of $657 \%$ was

BBC Focus on Africa, July-September 1997, p. 13. See also New African, March 1998, p. 26.

New African, June 1997, p. 21. See also Africa Confidential, 10 July 1998, p. 5.

African Research Bulletin, 30 November 1997, p. 12901. See also Africa Confidential, 26 September 1997, p. 5.

20 New African, April 1998, p. 22. See also Africa Confidential, 20 February 1998, p. 5.
} 
The conflict threatened to oust Kabila from power, but the Angolan and Zimbabwean forces saved Kabila and stopped the RCD advance on the western front, where Angola suffered substantial losses. The Angolan forces have been deployed only in defence of Angolan security interests in the western Congo-Kinshasa, while the Zimbabwean forces have also been deployed in the east. The number of deployed Zimbabwean troops have also increased substantially since the beginning of Zimbabwean involvement.

Angola and Zimbabwe are the most important allies of Kabila, but he has also found allies in Namibia, Sudan and Libyan-funded Chad. Kabila has tried to increase the manpower of his alliance by recruiting Tanzanian and Hutu soldiers. In addition, aid from military firms may also occur if the Kabila government is able and willing to pay for it. Kabila has therefore succeeded in combining a broad alliance of forces on his side.

The broadness of Kabila's alliance has made military co-ordination more important but also more difficult, especially because of the condition of the Congolese forces. Kabila's forces do not have a strong military intelligence apparatus, because of the destruction of Mobutu's apparatus in 1996-1997. Allegations of widespread bribery by rebels, absence from military action and alienation of the civilian population by looting, previously made against Mobutu's soldiers, are now made against Kabila's troops. ${ }^{28}$

Somewhat in contrast, the troops of Angola and Zimbabwe are considered to be among the better forces in Africa. Angola, Zimbabwe and Sudan also have some military capability in the air, whereas Uganda and Rwanda have virtually none. ${ }^{29}$ Nevertheless, the advantages of Kabila's allies have not necessarily had a huge impact.

Some of the allied troops are not used to the tropical local conditions. The tropical climate's unpredictability, heavy rains, landmines and bad roads have undermined planning and have impeded the large-scale movement of mechanised troops. RCD forces have also launched surprise offensives under the cover of bad weather to neutralise the air advantage of Kabila's allies.

Eventually, any substantial military progress against the RCD will depend on the non-Congolese partners of Kabila's alliance. Without the support of foreign powers, Kabila, like Mobutu during his 32 years of rule, would have been overthrown already. However, because of major foreign involvement, the rebellion has quickly escalated into a full-blown war involving most state and sub-state security actors in the region. The degree of involvement of the major actors has also escalated during this time.

\section{The rebel-dominated zone of influence}

On the rebel side, the military rulers of Rwanda and Uganda have been the major foreign actors. Similar to the rebellion of 1996-1997, the Rwandan Tutsi rulers considered threats to Congolese Tutsi interests in 1998 as the signal to project military power in the east of the Congo. The security of Tutsi communities in the whole region is the prime motivation for Rwandan participation in the 1998 conflict.

Much of the fighting of the RCD forces is still being done by Rwandan and Ugandan soldiers. Uganda and Rwanda can count, to some extent, on indirect financial

Business Day, 20 November 1998, p. 12. See also Cape Argus, 24 November 1998, pp. 1,3.

Hough, M., "The challenge of effective air power in sub-Saharan Africa" in Du Plessis and Hough, pp. 120-123. 
and military support from the USA and have strong logistical capabilities. ${ }^{30}$ The early deployment of substantial Ugandan forces deep inside the Congo distinguishes the 1998 conflict from the 1996-1997 conflict, when Uganda's involvement was less visible. Similar to 1996-1997, Museveni wants to weaken the Congo-based Ugandan rebel groups on the Congolese side of the border. However, Ugandan troops also fought soldiers from Chad at Bulia, Equateur, some 1400 kilometers from the Ugandan border. ${ }^{31}$ This incongruity may indicate military necessity or personal animosity towards Kabila, who turned against his erstwhile mentor Museveni.

Museveni and the Rwandan rulers have also played an important role in the creation and maintenance of the alliance against Kabila. While the Congolese Tutsi clearly formed the dominant element in the AFDL in 1996-1997, this time former members of the Mobutu army and politicians from Equateur are involved, also in Jean Pierre Bemba's Congolese Liberation Movement. Leadership rivalries and faction fighting have occurred among the rebel groups since late 1998, while deadly clashes have occurred between Rwandan and Ugandan soldiers who disagreed over which rival rebel group should be supported. ${ }^{32}$

The rebel alliance quickly established control over eastern Congo-Kinshasa. However, during the first six months of the conflict, the RCD forces have lost some of their momentum, in contrast to the AFDL forces that more or less maintained their momentum during the seven month campaign of the 1996-1997 rebellion. Similar to the 1996-1997 rebellion, local Bembe, Hunde and Nande militias temporarily joined Hutu militias in attacking Congolese and Rwandan Tutsi forces in the east. In reaction, the rebel alliance is negotiating with some local groups to lessen resistance to the RCD administration.

The Tutsi presence is just as unpopular as Kabila's rule, and Kabila, like Mobutu in 1996, uses anti-Tutsi sentiment to mobilize support. ${ }^{33}$ Nevertheless, because of proximity to the supportive Rwandan Tutsis, ethnic links and business interests the rebel alliance seems to have a better chance at maintaining some control in the east than the Kinshasa government ever had.

It remains to be seen, however, whether the rebel alliance will be equally successful to establish some authority in the Equateur region. The RCD rebel alliance under Wamba dia Wamba also is not necessarily in control of the Equateur rebel group of Bemba, which may affect the possibility of an effective ceasefire agreement if negotiations only include the RCD.

\section{The prospects for regional peace}

There are different ways in which the conflict can end, including a military victory, a ceasefire, a withdrawal of foreign troops and a domestic settlement. At the time of writing the rebel alliance still has the initiative, but the outcome of the war is uncertain.

Cornwell, R. and Potgieter, J., "A large peace of Africa?" in African Security Review 7 (6), 1998. pp. 74-86.

BBC Focus on Africa, January-March 1999, p. 21. See also New African, October 1998, p. 11 and Africa Confidential, 9 October 1998, p.5.

Sunday Times, 17 January 1999, p. 13. See also Business Day, 20 November 1998, p. 12 and Cape Times, 28 December 1998, p. 2.

De Volkskrant, 14 August 1998, p. 4. See also Newsweek, 7 September 1998, p. 25. 
The war in Congo-Kinshasa takes place in the Central African region where largely internal conflicts are also affecting Uganda, Rwanda, Burundi, Congo-Brazzaville, Sudan, Chad and Angola. Therefore, unexpected shifts in the power or composition of the governmentof a war participant cannot be excluded.

If the war participants agree to a ceasefire, it may not necessarily be a final solution. At the time of writing, a ceasefire will do little more than freeze the military standoff between the opposing forces, with the rebel alliance still occupying towns and areas in the east. However, if the conflict drags on without a decisive victory or defeat, major actors like Angola or Zimbabwe may begin to consider a withdrawal of their forces.

For Angola, the unexpected surge in UNITA activity since late 1998 may influence the extent or continuance of force deployment in Congo-Kinshasa. Already a substantial reduction of Angolan troops in Congo-Kinshasa has occurred. If the UNITA threat to the Angolan government becomes very serious, the RCD may be able to negotiate Angolan neutrality in the Congo in exchange for guarantees regarding oil concessions and the absence of UNITA bases in the Congo. If the Angolan forces remain deployed in the west only, this may be enough for the RCD to survive in the east.

In financially-stricken Zimbabwe, the high cost and limited success of Zimbabwean offensives against the RCD in the east have aggravated dissatisfaction among the population and military. ${ }^{34}$ Mugabe may find that continued participation in the Congo conflict begins to threaten his hold on power domestically. However, if Mugabe remains in power, it is possible that he will only withdraw his forces after receiving face-saving concessions and guarantees regarding concessions and war debts.

In contrast to Zimbabwe, the rulers of Uganda and Rwanda both have border security interests at stake in the Congo. The entry of Sudan in the conflict constituted an extra, direct threat to Uganda's security interests. The rulers of Rwanda and Uganda have gone to war twice in three years in order to safeguard their interests and little thought was given to the possibility of a negotiated outcome.

Similar to the 1996-1997 rebellion, the military campaign of 1998 did not only aim at securing the eastern border areas and at containing the insurgent threat from the eastern provinces. During both rebellions the objective also was to conquer Kinshasa and to remove the ruler considered responsible for the security threat.

Any permanent withdrawal of Ugandan and Rwandan forces is therefore unlikely unless these security concerns are addressed. The recent history of Tutsi genocide and the Hutu-Tutsi rivalries in the region mean that Tutsi survival as such is also at stake for the rulers of Rwanda. Given the strength of grievances and interests on the side of the Rwandan Tutsi rulers, it is unlikely that the withdrawal of Rwandan troops from CongoKinshasa will be effected without a settlement that also addresses the domestic political order in Congo-Kinshasa.

\section{The prospects for stability in the Congo}

Congo-Kinshasa still has a neopatrimonial political order based on state patronage of some groups and networks only. Exclusionary patterns of government patronage and perceived government harassment of certain regions and groups have regularly led to conflicts in the past. 
These conflicts are difficult to resolve. The concentration of control over resources in state structures also makes it attractive to excluded groups not to settle for less than a takeover of the state. Elite political pacts and compromise settlements are difficult in neopatrimonial orders, because of few institutional channels to negotiate rules and powersharing. Winner-takes-all struggles tend to be the rule, and the present conflict in CongoKinshasa is no exception. ${ }^{35}$

The different peace summits of 1998 mostly reflected the features of the winnertakes-all conflict. The peace summits did not progress beyond the exclusion or alienation of Congolese rebel interest groups by Kabila. The summits also did not clearly signal a change in the rebel sentiment that negotiations should only be about the specifics of Kabila's departure. ${ }^{36}$

On the one hand, a regional peacekeeping initiative may allow Kabila some respite to implement reforms. However, Kabila, who is struggling to fund his war effort, does not have many means to strengthen the political order. In addition, African peacekeeping forces, operating under financial constraints, will have difficulty to contain conflict everywhere and may aggravate xenophobia and instability instead.

On the other hand, if all the non-Congolese forces withdraw, local groups in the east will still be excluded from state patronage and the threat to Tutsis in Congo-Kinshasa and Rwanda will have remained. The reason for the two major recent conflicts in CongoKinshasa will therefore still exist after a foreign troop withdrawal from the country.

To accommodate the different actors, interests and discourses involved in the Congolese conflict, a comprehensive political settlement will be necessary. However, the Kabila government will probably be unable to unable to ensure a stabile political order providing a proper service to the whole population.

\section{Conclusion}

For decades Congo-Kinshasa has had a political order built around military force and personal rule, excluding different groups in the east from state patronage. The weakness of state control in the vast country, competing business and ethnic networks and the concentration of control over resources in state structures resulted in continuous local conflicts and attempts by excluded groups to take over the state by any means.

One such attempt was the rebellion of Congolese Tutsi and other groups in the east against Mobutu in 1996-1997. The rebel alliance was backed by Uganda and the Tutsi rulers of Rwanda, who were trying to protect their interests after the 1994 genocide of Rwandese Tutsi. The rebellion brought Kabila to power but left him with war debts, Mobutist dissidents, a smaller power base than Mobutu, a dependence on his military backers and expectations of state patronage among the Tutsi.

However, Kabila eventually diminished Tutsi influence and built a power base around his own group from Katanga. Like Mobutu, Kabila did not act against insurgent groups operating from his country against his previous allies Uganda and Rwanda.

Marley, A., "Problems of Terminating Wars in Africa" in Small Wars and Insurgencies, 8 (3), Winter 1997, pp. 109-115. 
Shortly after Kabila ordered the withdrawal of Rwandan Tutsi troops, a rebellion led by Tutsi troops erupted in the east in August 1998.

Congolese Tutsi, Ugandan and Rwandan troops provided the cutting edge of the new rebel alliance and quickly won control of the east from Kabila's fragmented military. Kabila was only saved by the military intervention of Angola, Zimbabwe and Sudan, which resulted in the escalation of the rebellion into a full-blown regional war. The support of Angola and Zimbabwe made it possible to stop a rebel offensive in the west of Congo-Kinshasa, but Kabila's allies were unable to drive out the rebels from most of the east.

On the one hand, the lack of progress against the rebels has increased the already high cost of the war for the Kabila alliance. The increased UNITA insurgent onslaught in Angola and the political turmoil in Zimbabwe have also put additional pressure on Kabila's allies to either win or settle.

On the other hand, the rebel dominance in the east, as well as the strength of the perceived interests of Rwanda's Tutsi rulers, make it unlikely that Rwanda will settle for a lasting peace without a new political dispensation in Congo-Kinshasa too. Such a political dispensation will need to accommodate the concerns of the eastern provinces and of the Tutsi too.

However, the impoverished and narrowly neopatrimonial state structures under Kabila will probably be unable to implement such a political dispensation in the east. In addition, neighbouring African rulers now know their ability to establish spheres of military and business influence in Congo-Kinshasa. To a large degree, the war since August 1998 reflects the continuing crisis of the state in Congo-Kinshasa. This crisis will not end with the end of the war. 